Cluster Article: Sensory Presence and Senses of Absence in the European Middle Ages

\title{
Sensuous reading in the Legatus divinae pietatis
}

\author{
Landon Reitz \\ Department of German, University of California, Berkeley, CA, USA.
}

\begin{abstract}
Devotional practices in the later European Middle Ages were highly somatic, and they utilized the human sensorium to convey, incite, and engender knowledge and experiences of the divine. Reading does not normally stand out as one of the more somatic devotional practices, but as demonstrated by the example of the Legatus divinae pietatis, a devotional text written at the convent of Helfta around the end of the thirteenth century, reading was indeed imagined as a somatic, devotional experience that engaged the senses. In this article, I argue that the Legatus portrays a form of devotional reading that invokes all the senses in an effort to unite the book, the reader, and her community with the divine. Drawing on medieval conceptualizations of the human sensorium and theories of reading, my analyses of the Legatus's sensual language, evocative imagery, and scenes of reading elucidate the embodied reading practices that the Legatus's writers portrayed as fundamental to their communal, devotional lives.
\end{abstract}

postmedieval: a journal of medieval cultural studies (2021) 12, 219-236.

https://doi.org/10.1057/s41280-021-00219-7

The Legatus divinae pietatis (Herald of Divine Love), a devotional text written by Gertrude of Helfta (c. 1256-1302) and other women at the convent of Helfta, sought to incite direct sensory experience with and intimate knowledge of God. ${ }^{1}$ By the end of the thirteenth century, when the Herald was composed, devotional practices had widely embraced the physical senses as vehicles to

1 For more about the life of Gertrude of Helfta, see Ruh (1990, 1992). 
2 Casagrande (2016) argues for a strong 'turn' in the

understanding of the senses from naturally sinful to naturally inculpable; however, it is more accurate to speak of a tempered shift since the senses were neither completely disparaged previously nor entirely embraced afterward.

3 For example, Hamburger (1998) and Jung (2010).

4 See Poor (2004, 6-9) for a concise overview of the scholarly debate on how to interpret seemingly (auto)biographical mystical and visionary texts. I agree with Poor that such texts are most likely a complex combination of historical truths and literary constructions. move the soul toward God, despite the earlier warnings from theologians such as Augustine and Gregory the Great that the physical senses were inadequate, sinful, or otherwise incompatible with experiences of the divine (Newhauser, $2014,2) .^{2}$ Food, paintings, sculptures, incense, and music purportedly initiated vivid visions of Christ and sensuous encounters with him among devotees. The Herald has often been cited as evidence for the senses' integral role in the incitement and experience of divine encounters for the few people who received them. ${ }^{3}$ However, portrayals of such events in which holy women see, feel, taste, and come to know God were rarely included in devotional literature as mere witnesses to historical events. ${ }^{4}$ Instead, they formed an integral part of a larger rhetorical scheme meant to generate and convey divine knowledge and experience through devotional practices. ${ }^{5}$ This article, therefore, asks how and to what end the sensuality of Gertrude's purportedly lived experiences was converted into textual form in the Herald. For a devotional text replete with sensuous language, imagery, and metaphors, what roles were the senses meant to play in its reading and reception, and what conception of the human senses did those roles imply?

In this cluster of essays on sensory studies and the Middle Ages, Mareike Reisch and Lora Webb analyze figural and aesthetic representations of the human senses, and Danny Smith considers the stimulation of feelings generated by works of art. My contribution encompasses these two approaches as I examine how the Herald first represented and then aroused the senses. I focus specifically on the role of reading in mediating and activating the senses because the Herald's rhetorical appeal to them was accompanied by a comprehensive conceptualization of devotional reading practices that revolve around the material status of the book, the phenomenological experience of reading, and the corporeality of the reader. The Herald's presentation of reading as a physical act involving bodies and objects that ignite the senses is exemplary of a key paradox in late medieval piety, namely, that objects and materials were increasingly understood to contain and express the divine even in a religion characterized more and more by interiority, negative theology, and mysticism (Bynum, 2011). ${ }^{6}$ The Herald presented itself as just such an object, a material book that incites sensory experiences meant to deepen the personal relationship between devotees and Christ. ${ }^{7}$

Recently, Jessica Barr (2020) has convincingly argued that the Herald's portrayal of itself as a material book with corporeal attributes suggests that it served as the meeting point for intimate interactions between the body of the book's reader and the imagined body of Christ. My argument builds on this idea of intimate reading in the Herald by investigating the activation of the human senses through sensual language, evocative imagery, and the phenomenological experience of reading and the senses' subsequent role in achieving union with the divine. The Herald employs rhetorical techniques, sensory language, and appeals to material objects to engage the senses - both the so-called inner and 
outer senses - and ignites the imagination so that readers can experience God with their entire bodies. These techniques are supported by a specific concept of embodied reading that is demonstrated and spelled out in scenes that depict the Herald's formation and reception.

By analyzing these scenes, I will argue that not only is the codex as object a meeting point for intimate interactions with the divine, but it also becomes a physical and symbolic representation of Christ that the reader is encouraged to taste, smell, and touch in her own way. From there I will extrapolate a conception of reading held by the women at Helfta in which reading is a sensory experience that, if done properly, unites the text, the book, the reader, and God with one another. I will also make the argument, based on the communal devotional practices at Helfta, that the sensuous reading practice portrayed in the Herald united the women of this religious association into both a textual and a sensory community. ${ }^{8}$ Ultimately, I will show that the devotional potential of this text is centered on neither the retelling of Gertrude's visions nor a hermeneutical explanation of the divine, but rather on the sensual experiences the text encourages between the reader's body, the book's text, and Christ.

\section{The Herald's historical and devotional contexts}

The convent of St. Maria at Helfta was a center for religious learning and writing in the second half of the thirteenth and the beginning of the fourteenth centuries, when it produced various mystical texts that explored theological and devotional themes framed within a search for knowledge of the divine through union with Christ. ${ }^{9}$ They include meditations, prayers, visions, and anecdotes about the daily lives and devotional practices of the women in Helfta that make it clear that these texts themselves were an integral part of the women's routine devotional activities (Löser, 2012; Nemes, 2014). All the texts produced in Helfta are believed to be a communal effort since several include stories about their composition in which multiple figures are involved and since all have textual evidence of other writers, editors, and/or endorsers. ${ }^{10}$

Notions of community were such a prevailing concern in the Helfta writings that this Benedictine/Cistercian convent can be seen as a prime example of Brian Stock's notion of a textual community, both within its own walls and as part of an elaborate monastic network (Stock, 1983, 90). ${ }^{11}$ At a local level, its texts functioned as both devotional manuals and memory archives for the sisters in Helfta around which their community identity coalesced (Hubrath 1997; Bürkle, 1999, 178). At a broader level, the Cistercians in Western Europe also constituted a textual community in that they developed and propagated shared reading and hermeneutical practices that swung dialectically between text and experience (Stock, 1983, 405). Such a monastic reader 'engaged his mind and his senses' when reading in an attempt to rehearse, revivify, and relive the recorded
5 For the integral role of sensory perception in medieval devotional practices, see Hamburger's fundamental work on images and vision (Hamburger 1998, 2000a, 2000b), Jung (2010) on touch, Biernoff (2002) on vision as a physical encounter, and Williamson (2013) for inaudible sounds and invisible images.

6 For an analysis of religious objects intended to incite sensory experiences for devotional practices, see Bagnoli (2016a), and for medieval sensory objects more generally, see Griffiths and Starkey (2018).

7 Recent scholarship has shown that the materiality of manuscripts organized and regulated reading bodies through embodied forms of reading (Amsler, 2011), 
incited affectual reading practices (McNamer, 2010), and created sacred spaces where the five senses could be activated in the production of meaning (Camille, 1998; Palazzo, 2010; Dillon, 2012).

8 For the concept of sensory communities, I draw on Newhauser (2015) and Griffiths and Starkey (2018).

9 Under the leadership of Gertrude of Hackeborn (d. 1292), the convent of Helfta became an intellectual and theological center. The other wellknown writers associated with Helfta are Mechthild of Magdeburg (d. 1280/90) and Mechthild of Hackeborn (d. 1299). For the history of the convent and its textual production, see Kirakosian (2021, 13-19). experience. His 'grasping of the inner meaning depended largely on his ability to come to grips with what was before him on the page,' a process that required close interaction 'between the text, his self, and his faith' (Stock, 1983, 409). This interaction engendered the creation of an experience rather than the mere conveyance of discrete objective knowledge, an experience which was available to all devoted readers. This Cistercian understanding of reading as an interactive experience between text, self, and faith through the activation of the senses underlies the rhetorical program of the Herald. The Herald presents this experience as an interaction among bodies facilitated by sensuous acts of reading. The text's appeal to the body's senses bridges the ostensible gap between the human and the divine while also creating the possibility for a shared communal experience.

Attitudes toward the role of the bodily senses in the search for experience and knowledge of the divine evolved over the centuries, but by the twelfth and thirteenth centuries, the depiction and language of mystical experiences were increasingly somatic. An Aristotelian understanding of the senses as the source of physical sensation and the first step toward knowing became prevalent in learned circles (Camille, 1998, 33; Bagnoli, 2016b, 23), while late medieval devotion increasingly focused on Christological practices including a greater veneration of Christ's body. Devotees and theologians alike focused on the tension between the divine and human elements embodied in the person of Jesus Christ, the incarnate God in whom body, soul, and divinity are one. The overall interests in 'the human Jesus, [a] hunger for his direct bodily presence in the Eucharist, and [a] desire to gain holiness and access to God by physically imitating Jesus and his followers' influenced many mystical theologians to believe that human 'bodies have a central role in our approach to and union with God' (Rudy, 2002, 5).

The writings of Bernard of Clairvaux were highly influential in the application of this heightened role of the human body in experiencing the divine in devotional texts. Unlike earlier theologians such as Augustine, Bernard did not explain away sensory language in the scriptures as mere surface text or metaphor; instead, he understood it as affective on a single human sensorium that could be directed at material and bodily things as well as spiritual and divine things (Rudy, 2002, 36-7 and 45). This single human sensorium represented a fusion of the dichotomy between an outer set of senses for perceiving worldly, material objects and an inner set of spiritual senses for perceiving divinity that had originated with Origen of Alexandria's biblical commentaries and greatly influenced subsequent understanding of the human senses (Rudy, 2002, 25). Despite the supposed split, Origen still suggested that both sets of senses were vital to correct interpretation of the scriptures. For as Niklaus Largier recognizes, Origen proposed that the holy scriptures do not just convey a historical understanding (as in a form of discrete knowledge) but also engender a new reality of vividly sensual ('sinnlich-anschaulicher') experience in 
which the senses play an important perceptive role (Largier, 2007, 50). Bernard's writings, in a way, renewed the close interaction between internal and external senses when he embraced the knowledge provided by external sensory perception and employed sensory language based on the more immediate senses of taste and touch in kissing and embracing to portray the immediacy of union with God and with the humanity of Christ. Bernard's influence extended to the writings of Hadewijch of Brabant, Bonaventure, Mechthild of Magdeburg, Rudolf of Biberach, Jan Ruusbroec, and Richard Rolle, in which 'an integrated notion of the mystical self [is present] that saw the outer and inner aspects of sensation - feeling, desiring, perceiving and knowing - as part of a continuum of conscious and progressive reception of divine gifts' (McGinn, 2012, 209).

The Herald falls squarely into this tradition as it attempted to convey knowledge of the divine not so much in abstract concepts or metaphors as through relatable bodily sensations. However, it nevertheless ran into issues of linguistic mediation when it attempted to express via text knowledge that was originally won through the senses. Gertrude of Helfta and the other contributors to the Herald were aware of this issue, and as a solution, I suggest, they presented the act of reading as an experience that could be sensed by the reader.

\section{The book as Christ's body}

Unfortunately, there are no existing manuscripts of the Herald from the convent of Helfta (Nemes, 2014, 106-10) that would allow us to contemplate the exact kinds of material objects and sensory interactions the women of Helfta had when reading the text. (In contrast, Arthur Russell is able reconstruct this experience through the extant late medieval prayer bead program in his contribution to this current cluster of essays.) However, the Herald provides portrayals of embodied reading practices and imagined sensory interactions for which a similar phenomenological approach can be applied in an attempt to understand the role of the senses in the connection between reading bodies and reading materials. ${ }^{12}$

The reading practice presented in the Herald is predicated upon a complex metaphorical, ontological, and theological relationship between Christ, the reader, and the material book, all three of which are predominantly portrayed as bodies and described in sensory language. Christ and the reader, at least implicitly, already have bodies, but the Herald also presents itself - metonymically as text and codex - as an embodied object, often either as an embodiment of Christ's divinity or an object to be consumed or incorporated by another body. As Jessica Barr notes, the Herald first takes shape when it is written on Gertrude's body, which 'becomes a divinely authored text to be read, first in the process of composition and subsequently by her audience' (Barr, 2020, 166). This embodied textuality of the Herald is portrayed in the second Book, where
10 Gertrude is believed to have written Book 2 while the other books were written by other women at Helfta, perhaps with her consultation but also after her death. For the history of collective writing practices at Helfta, see

Hubrath (1996, 1999), Kolletzki (1998), Grimes (2007), Harrison (2008), Nemes (2019), and Kirakosian (2021).

11 For analyses of community in the writings from Helfta, see Hubrath (1996) and Voaden (1997).

12 For another insightful phenomenological approach to readers and their manuscripts that also suggests intellectual and visual stimuli gathered by medieval readers could be felt throughout the body, see Borland (2013). 
13 Citations of the Herald refer to Gertrude d'Helfta (1968, 1978, and 1986) and are cited by book/prologue, chapter, paragraph, and line numbers. English translations of passages from Book 5 are from Nemes (2014), while all other English translations are my own in consultation with Alexandra Barratt (Gertrude the Great of Helfta, 1991; 2018) and Johanna Lanczkowski (Gertrud die Grosse von Helfta, 1989). the word of God rains down on a struggling, doubtful Gertrude. Her body is too weak to absorb anything useful except some profoundly significant words, which, however, her inadequate human understanding cannot grasp: she is 'a delicate and tender little shoot' flattened to the ground by the heavy beating of the rain (2.10.2.4-11). ${ }^{13}$ Gertrude's ability to absorb words that she cannot understand and then pour them out onto the page as if they were her own suggests that her encounter with God is more embodied than intellectual (Barr, 2020, 168). In this scene, Gertrude's body first receives the text, giving it a physical form, and then she uses her body to further convey the words through writing; in effect, her body becomes the medium on which, and then the medium through which, the book is written. The text, or so this imagery suggests, seeks a material support and strives to gain a bodily form.

The codices containing Gertrude's inspired writing gain corporeality when, for example, Christ appears holding a completed version of the Herald in Book 5 and says: 'I have pressed this book which is mine deep into my divine breast to saturate every single letter written in it with the sweetness of my divinity, as sweetest mead drenches a bite of fresh bread with sweetness, so that each one who reads it in humble devotion for my praise will gain the fruit of eternal life' (5.33.1.3-9). In this scene, Christ approves the text by infusing every letter with His divinity - implying that the text itself was hollow and lacked any inherent power. This infusion is presented in strikingly familiar physical and sensory terms through the simple act of soaking up mead with bread that promises a sweet and tasty mouthful. Christ fills the book with divine substance by bringing the book into contact with His body, thereby transmitting His divinity into the book. His actions suggest that God's divinity can be housed in and channeled through material objects and bodies via touch. The unmediated role of touch in the union of two bodies foreshadows the divine effects of the mystical touch, kiss, or embrace.

Significantly, both of the above scenes comprise parts of the book's origin story. Such genesis stories enable the reader to conceptualize what exactly this book is and how it should be regarded, read, and interpreted. Much of the Herald's origin story is concerned with endowing the text - usually presented as a finished codex - with divinely inspired origins, a corporeal form, and the sanctity of a relic. The genesis story of the Herald thereby implies that the book is analogous to (if not an extension of) Christ - divine essence incarnated - and that it should be read and handled not just as a holy text but as Christ's body.

In this origin story, the somatic imagery reflects a certain treatment of the theological problem of knowing the divine. Divine essence is described not as a material object but as a quality. This quality can only be explained through an appeal to sensory perception, like rain with its overwhelming wetness and mead with its sweetness; yet it is the unquantifiable wetness and sweetness themselves that hold the mark of the divine, not the rain or the mead, strictly speaking. These sensory adjectives, importantly, do not function as metaphors (as if His 
divinity is as sweet as mead); instead, the sweetness is a clear sign that Christ's divinity is present, a sign that the human body can perceive the divinity just as it can taste the sweetness of mead.

The additional mention of the 'fruit of eternal life' that is offered to the book's reader underscores the book's contents as sweet-tasting and introduces the notion of the book being something to be consumed. The image of mead-soaked bread evokes the act of consuming Christ's body in the form of the host, especially since the Eucharist becomes an explicit image just a few lines later when Christ declares: 'Through the same power by which, at mass, I have transformed the bread and wine for the salvation of all, I have sanctified everything written in this book by my heavenly blessing for the true salvation of all those, as I have said, who read it in humble devotion' (5.33.1.13-17). By invoking the power of transubstantiation, Christ transforms the substance of the book into His own body and blood, making it accessible to Christians through the act of reading. The analogy with the Eucharist and the evocation of the sense of taste imply that reading the book is like consuming the book, which gives the reader license to experience it in sensory terms.

A connection between Christ and the book is also created through the sense of smell. After Christ uses the power of transubstantiation to sanctify the words of the book, Christ praises the book's writer, saying that 'she had adorned me with as many vials of perfume as there are letters in the book' (5.33.1.19-21). This imagery endorses the author's writing while also presenting Christ's body as a perfumed object to be enjoyed in sensory terms. The metaphorical connection between the number of perfume vials and the number of letters in the book both sets the writer's work into material terms and creates a sensory analogy between the smell of the vials and the perception of the text, thereby conflating the sensory experience of Christ's body with that of the text.

The Herald - as book - figures as Christ's body in yet another way in this passage. Shortly after the comparison with the Eucharist, Christ decorates the book to show that its contents come from him: 'For I will cover this book which even now I often have called mine with my most holy life and adorn it with the rose-coloured jewels of my five wounds and seal it with the seven gifts of the Holy Spirit, as with seven seals, by my divine might, so that no one shall be able to pluck this book from my hand' (5.33.1.32-7). The wounds, elements of Christ's own body, adorn the book as jewelry, again suggesting that the book is the body of Christ. There is a rich tradition of equating books with Christ's body or considering them as incarnations of logos; for example, the Bible has passages where the holy text functions as a metonymic realization of the absent God, and many medieval manuscripts containing the holy scriptures were decorated and treated as reliquaries for the body of Christ (Wenzel, 1995, 344-56). Codex Bibles were often richly decorated with gold, ivory, and jewels and paraded around or prominently placed in public view during rituals to symbolize the presence of Christ. When ostentatiously decorated in this way, the Bible 
embodied the high value and mystical meaning of the text in material form and functioned less as a communication medium than as a sacred signifier expressing the mystery and truth of faith (Wenzel, 1995, 351). The scene from the Herald, then, evokes the creation and decoration of just such a reliquary.

This decoration of the finished codex with Christ's wounds makes the book a multisensory object appealing to the sense of sight and tactile perception. Christ's wounds are ever-present in medieval meditations, as they powerfully recall the Passion. Christ's side wound was particularly venerated as a doorway that could be penetrated to reach His heart or opened up to allow the outpouring of His divinity (Bynum, 2007, 14-15; Hamburger, 1997, 164 and 219). Similar to the bread of the Eucharist, which allows Christ to be tasted, these wounds can be touched to access Christ in the Herald. In an earlier vision, Christ presses Gertrude against His side wound to substantiate her divine inspiration. When Gertrude, humbly expressing doubt that God would genuinely grant her the gifts of the spirit, asks her friend Mechthild of Hackeborn to seek advice directly from Christ, Christ appears to Mechthild, 'embracing the one [Gertrude] for whom she prays, with His right arm, so that her left side - where the heart lies - was fastened to the opening of His wound of love' (1.16.1.15-18). Mechthild wonders what this vision means, and Christ explains to her that 'by seeing [Gertrude's] heart attached to my side wound, you should realize that I have prepared her heart so, that she can directly absorb the flow of my divinity at any time' (1.16.1.25-8). Christ's inner divinity thus flows directly to Gertrude's heart through His side wound. In summary, the Herald depicts its own codex form as a body that both interacts with and stands in for Christ's body, a consumable object that acts as a vessel for the essence of the divine.

\section{Sensuous reading in the Herald}

Since the Herald portrays the book as a physical body that holds the divine essence and is to be tasted, touched, sniffed, and seen, it follows that it also portrays a method of reading that foregrounds physical interaction and sensory perception. In the Herald, where the textual object is the mediator of divinity, accessible through an affective and sensory experience, the reader's body becomes the focus of reception. The key role of the reader's body is apparent in several scenes of reading in which sensual language and imagery are employed to both portray and engender a sensuous reading practice. These scenes depict the sensation that its characters experience when reading, demonstrating how reading can lead to bodily sensation. Simultaneously, the sensuous language in these passages extends the sensual experiences of the characters in the text to the actual reader of the book. In this way, the scenes of reading in the Herald 
explicitly demonstrate and enact how the sensual language of the text is transformed into sensual perception for the reader.

These scenes depict, in some ways, the theory of reading described by Hugh of St. Victor in which the effect of reading on a reader is compared to the effect of music on a listener. The sensual rhetoric is set in a particular context so that its persuasive effect is employed in the form of a sensual experience - in its reception, the 'explicatio' ('explication') of the text passes over to an 'applicatio' ('application') that empties the text of its meaning and converts it into a vividly sensual 'experientia' or 'cognitio experimentalis' ('experience' or 'experiential knowledge') (Largier, 2007, 45). The sensual rhetoric of the Herald's reading scenes encourages such a reading experience that transcends the traditional distinction between inner and outer senses and bodies. In these scenes of reading, the Herald conflates the sensual experience of the figures, the rhetoric of the text, and the actual reading experience of the devotional reader.

In Book 2 of the Herald, Gertrude lays out a brief theory of reading using a complicated set of metaphors that combines the process of reading and understanding with an act of eating. Comparing the reader to a student, she portrays the reading process as an intensification of understanding:

May [readers] achieve personal experience of ampler graces in their innermost being, just as a student arrives at the rules of logic by way of the alphabet! In the same way, may they, who read what has been recorded here, be led by these pictures of the imagination to taste within themselves that hidden manna, that can through no physical conception be conveyed. Whoever tastes it once, hungers for it forever. (2.24.1.12-17)

This prayer mixes metaphors to a dizzying degree: the process of reading this book is compared to a student's intellectual maturation, in an escalation of intellectual activity from letter learning, to learning how to read, and finally to learning the structures of logic and thought. Furthermore, the reader is described as hopefully being led to God's hidden love by means of 'pictures of the imagination.' But these metaphors drawing on intellectual capacity are undermined by the image of heavenly manna and the evocation of the bodily act of eating. There is a tension, too, in the fact that Gertrude says this heavenly manna cannot be portrayed in physical terms, yet she simultaneously appeals to the sense of taste to convey the greatness of God's love. Another source of tension arises when, despite the intellectual work the first few metaphors imply, Gertrude ultimately compares what is won from the reading process to food provided by God that literally falls out of the sky with no human effort required. The desire such a taste evokes is also portrayed affectively as an 'eternal hunger' - a description that combines both human (hunger) and divine (eternity) characteristics. Gertrude inserts this physical description of reading's reward right at the moment when, presumably, intellectual description fails to grasp the meaning or experience; yet the somatic description relies on the intellectual 
build-up to effectively portray the acquisition of divine knowledge. Thus, we see a process that grants the reader's body what we might call both cognitive and affective capabilities that guide her from reading to understanding to sensual experience.

A similar example of this process appears at the end of the Herald. The writer prays that the book will prove fruitful for every reader and then calls out the simpler readers of this book, those who are not able by themselves to swim in the stream of divine grace' $(5.36 .1 .18-20)$. Such readers 'may at least travel by this vehicle and rejoice that they, too, may be led by the hand through their neighbour's gifts of grace until finally they begin to taste, by reading, meditating and contemplating, how sweet the Lord is' (5.36.1.20-4). As before, the text portrays the progression of a novice in a process that builds up through stages of intellectual and imaginary work to culminate in a sensory experience, the tasting of the sweetness of the Lord. These instructions exemplify the type of exercises necessary to construct the inner senses and the space where the distinction between inner and outer senses can be transcended. In the Herald, that space is created through the sensuous interaction between the reader, the text, and the divine. The passage also specifically signals the intermediary stages of meditation and contemplation. These practices are essential to internalizing the reading experiences presented in the Herald and connecting the external senses with the inner senses, for they encourage the reader to dwell on what has been read, savoring the invoked physical sensation and growing the capacity of the inner senses. The Herald seems not to draw any great distinction between the inner senses as spiritual senses and as cognitive functions. Inner seeing, tasting, and hearing in devotional practices designated a type of spiritual understanding that knows something about the divine but does not require absolute knowledge. Thus, the 'goal of affective mysticism is,' as Patricia Dailey argues, 'to allow one's affective and thus embodied experience to stimulate the construction of the inner body and then to allow the heart, innards, or inner senses to speak and act through the outer body. [...] The inner is developed so that it may become a reality that dominates, scripts, and bestows sense on the outer' (2012, 269). Reading is the practice within medieval devotion that enables the outer senses to build the inner body and sharpen its senses for reception of the divine. Once the inner body begins to sense and receive the divine, it can channel its reality onto the outer body, sharpening its perception of the world or directing its actions, including acts of praying, writing, and preaching.

Various scenes in the Herald demonstrate the formative role of the outer senses for the inner senses, and then the executive role of the inner body over the outer. When Mechthild receives the vision meant to reassure Gertrude that she is divinely inspired, for example, Christ explains to Mechthild that His heart is inseparably united with Gertrude's soul so that they are one spirit. Their wills 
correspond 'as if members of her body were in harmony with his heart just as a thinking man is in control of his heart: when he decides to do something, immediately the hand completes it' (1.16.2.9-11). Then Christ takes the corporeal metaphor further:

she is like my right hand, with which I accomplish what I want. And her insight is for me my eye, because she recognizes what pleases me. And the drive of her spirit is to me a tongue, since she, driven by this spirit, speaks what I desire. Her discrimination is to me a nose, because I lend the ear of my mercy to him, to whom she through compassionate love turns. Her intent is to me my feet, since she aspires for that, which is necessary to follow me. (1.16.2.17-25)

This passage demonstrates exactly how the internal qualities and senses of the mystic are connected directly to God and to external actions. Gertrude's will is Christ's right hand through which he works; her insight is His eye; the drive of her spirit is His tongue with which he speaks. These direct equivalencies destabilize the difference between metaphorical and literal use so that one can no longer be sure what the instrument is that accomplishes all God's work: is it the eyes, the feet, or the tongue? Or the insight, the intent, or the drive? The devotee is united with Christ in that her internal faculties form parts of His physical body.

Such a union, in which one's primed inner faculties have merged with the divine and have begun to effect one's outward perception and actions, is available to the reader as well. We can see this mystical power, for example, in the scenes of reading that use imagery of breath and breathing to depict a close connection between the inner and outer bodies as well as human and divine bodies. One such scene occurs already in the prologue when Gertrude presents the first part of the text to Christ, who reassures her:

When a person in humble devotion desires to read in this book for the sake of spiritual progress, I will draw him toward me so that he will read in the book as if between my hands, with him I will join myself in this work, as it happens when two people read off of the same page: one senses the breath of the other. ${ }^{14}$ I will absorb the breath of the desire of the reader in me, whereby my pious flesh shall be stirred up over it. Furthermore, I will breathe on him with the breath of my divinity, and so will this person be internally renewed through my spirit. (Prologue.2.9-17)

This intimate scene constitutes what Barr calls a 'textual encounter' between the reader and Christ (Barr 2017, 2020). In the act of reading portrayed, the relationship between Christ, the reader, and the book is demonstrated through their physical placement - Christ pulls the reader in so closely that she can read the book as if between Christ's hands. The positioning of the reader (and probably the book, too) between Christ's hands functions as both a display of

14 In these passages of the Herald with references to unspecified, hypothetical readers, translators have conventionally rendered the pronouns with the generic masculine. I maintain this convention for consistency but, given the intellectual vibrancy of the Helfta women, I prefer to imagine a female reader in my analysis of these passages. 
15 Such physically intimate conceptions of devotional reading are attested by surviving manuscripts of other devotional texts that show physical signs of being caressed and kissed by the reader; see Amsler (2011, 133-7) and Rudy (2010). affection and a gesture of guidance or supervision. The intimacy of the reading scene is increased when the reading bodies are united through an exchange of desirous and rejuvenating breaths that continuously and uninhibitedly transgress the boundaries between the reader's inner and outer bodies. This movement of breath takes place under the conditions of reading, the proper intentions of the reader, and the auspices of divine presence. It is a movement analogous to the transference of the external perception of the book to some sort of internal comprehension or perception.

The image of reading with God emerges again in the final book of the Herald. In this vision, Gertrude brings her book to Communion, secretly hidden in her habit, but the Lord sees it and again infuses all the words with the sweetness of His divine love (5.34.1.9-11). But now instead of explaining the nature of the book, Christ speaks about the reading process, almost parroting His words from the preface:

And I will take whoever comes to me with a humble heart, desiring for love of my love to read this book, onto my lap and with my finger point out all specifically that is beneficial for him. And I will incline myself graciously towards him, so that, in the same way that someone who has been sated by both species of the Eucharist breathes onto the one who wishes to kiss him, I will breathe into the reader efficaciously with my divine breath to effect his soul's salvation. (5.34.1.11-19)

Again, the book serves as the meeting point where Christ takes any humble reader onto His lap and guides her reading. The scene begins with the didactic act of Christ pointing out beneficial passages, but then it moves on to a sensuous, bodily act of Christ breathing into the mouth of the reader to effect her soul's salvation. The comparison here to the Eucharist recalls the experience of taking the body and blood of Christ into one's own body, a communion with the divine through a physical vehicle. Meanwhile, the image of a kiss conjures the intimate union of bridal mysticism, the unification of Christ with His bride through physical touch. Thus, reading is presented as an act of bodily consumption and sensation that brings the reader together with Christ. ${ }^{15}$

\section{Communal reading in the Herald}

The portrayal of bodies intimately interacting with each other over a shared book necessarily presents reading as a communal activity. Whether the reading experience is shared with any one of the many holy figures (John the Evangelist, heavenly angels, Christ, etc.) portrayed among the Helfta community in the Herald or with fellow sisters, the reading practices depicted are not solitary events. The evidence of communal writing practices drawn from depictions of events in the Herald as well as scholarly analyses of the authorship of individual 
books already mentioned in this article support an overall set of communal textual practices. Even if a reader did not read the Herald seated physically next to a fellow sister, when she read about her fellow sisters experiencing the divine, the sensory language and scenes of reading would have led her to perceive her sisters' experiences and to imagine the presence of the divine in her immediate surroundings. In effect, she would have become that reader whom Christ describes as reading the Herald on His lap, and she was thereby joined to the community of holy women writing, reading, and disseminating this text. The scenes of reading, through their evocation of physical, sensual reading, extend this notion of community engagement to readers distant from Helfta in both time and space, to all those who imagine themselves in the figure of the unnamed reader and experience the physical presence of Christ in their interaction with the book. Reading the Herald in this way reminds the reader of the community she is part of, whether the specific community of the monastery at Helfta or the broader community of believers united through their sensuous experiences of the divine.

The final scene of reading I wish to present is a negative example, one that expresses through sensory language and physical interaction how a reader could be left without divine support and could position herself as an errant individual outside of the holy community. All the readers portrayed thus far have pure hearts and pure intentions, but now we encounter a false reader who

is spurred on by curiosity and self-aggrandizement to come to me [Christ] underhandedly, leaning as it were on my back to spy over my shoulder and scan the text of my book to pervert it: I will not suffer the burden of his weight for a moment; I will not hesitate to destroy the disgraced with my divine power. (5.34.1.19-24)

The reader approaches the text both literally and figuratively from behind, perverting the bodily interaction required for devotional reading: Christ cannot guide her reading, kiss her mouth, or breathe into her soul. She keeps a jealous watch over the book, inspecting (perscrutari) the text as if looking for flaws to exploit, rather than reading or gathering (legere) the words of Christ uncritically like the good readers described in the Herald. Additionally, Christ feels the false reader as a burden, unlike the good reader who sits weightlessly on Christ's lap, conveying a simple binary opposition between reading practices through physical sensation. Finally, the reader's position behind Christ's back marks her independence or, more negatively expressed, her refusal to engage in communal reading practices, further supporting, by negative definition, the communal identity established through the act and practice of correct reading. Such a physically, intellectually, and socially distanced stance, one that eschews the outer senses and prevents the reader from engaging and experiencing the sensuous, somatic mode of reading necessary for a cultivation of the inner senses, marks her as a disgraced reader. ${ }^{16}$

16 For an analysis of how vernacular adaptations of the Herald reworked and extended the imagery of reading and writing into embodied forms of becoming the bride of Christ that sanctioned their work and practice as receptive, creative readers, see Kirakosian (2021, 126-47). 


\section{Conclusion}

Devotional reading as presented in the Herald is not just an intellectual pursuit, a pure function of the imagination, or an immediate affective reality; instead, the devotional writers of the Herald, who were also devoted readers, portrayed sensuous reading as the catalyst and means for constructing an inner body, where an intellectual, internal understanding is intensified by sensual responses and vice versa. Described in the Herald using sensual imagery, reading unites Christ and the reader as well as the reader's own inner and outer bodies through an aesthetic 'applicatio' ('application') that emancipates the fallen nature of the human sensorium. By aestheticizing reading practices into bodily reading scenes through sensuous, somatic, theological, and intellectual metaphors, the Herald portrays devotional reading as one aspect of the complex mystical and devotional practices that engage the body, mind, and soul, combining intellectual and carnal epistemological modes.

Gertrude and her fellow sisters employed theological tenets like transubstantiation and religious practices like consuming the Eucharist, contemplation, and meditation in order to imagine the power of reading. Their writing seems to be unique in its theological, imaginative, and rhetorical depiction of devotional reading practices, while, as my analysis has shown, the conception of reading presented in the Herald fits squarely within other contemporary theological frameworks and discourses on reading. By reimagining reading through sensuous metaphors that compare it to processes of touching, eating, smelling, seeing, and breathing, these women portrayed reading as an intimate practice intertwined with other complementary practices and beliefs that modeled and reinforced their communal religious way of life.

\section{Open Access}

This article is licensed under a Creative Commons Attribution 4.0 International License, which permits use, sharing, adaptation, distribution and reproduction in any medium or format, as long as you give appropriate credit to the original author(s) and the source, provide a link to the Creative Commons licence, and indicate if changes were made. The images or other third party material in this article are included in the article's Creative Commons licence, unless indicated otherwise in a credit line to the material. If material is not included in the article's Creative Commons licence and your intended use is not permitted by statutory regulation or exceeds the permitted use, you will need to obtain permission directly from the copyright holder. To view a copy of this licence, visit http://creativecommons.org/licenses/by/4.0/. 


\section{About the Author}

Landon Reitz is a Graduate Student in German and Medieval Studies at the University of California, Berkeley. He received his BA in Medieval and Early Modern English Literature from the University of Pennsylvania in 2011 and his MA in German Studies from UC Berkeley in 2016. His work analyses the conceptualization and portrayal of reading as presented in German-language literature from the Middle Ages to today.reitzls@berkeley.edu

\section{References}

Amsler, M. 2011. Affective Literacies: Writing and Multilingualism in the Late Middle Ages. Turnhout, Belgium: Brepols.

Bagnoli, M. 2016a. Longing to Experience. In A Feast for the Senses: Art and Experience in Medieval Europe, ed. M. Bagnoli, 33-45. Baltimore, MD: Walters Art Museum.

Bagnoli, M. 2016b. Making Sense. In A Feast for the Senses: Art and Experience in Medieval Europe, ed. M. Bagnoli, 17-30. Baltimore, MD: Walters Art Museum.

Barr, J. 2017. Imagined Bodies: Intimate Reading and Divine Union in Gertrude of Helfta's Legatus. Journal of Medieval Religious Cultures 43(2): 186-208.

Barr, J. 2020. Intimate Reading: Textual Encounters in Medieval Women's Visions and Vitae. Ann Arbor, MI: University of Michigan Press.

Biernoff, S. 2002. Sight and Embodiment in the Middle Ages. New York: Palgrave Macmillan.

Borland, J. 2013. Unruly Reading: The Consuming Role of Touch in the Experience of a Medieval Manuscript. In Scraped, Stroked, and Bound: Materially Engaged Readings of Medieval Manuscripts, ed. J. Wilcox, 97-114, plates 225-30. Turnhout, Belgium: Brepols.

Bürkle, S. 1999. Literatur im Kloster: Historische Funktion und rhetorische Legitimation Frauenmystischer Texte des 14. Jahrhunderts. Tübingen, Germany: Francke.

Bynum, C.W. 2007. Wonderful Blood: Theology and Practice in Late Medieval Northern Germany and Beyond. Philadelphia, PA: University of Pennsylvania Press.

Bynum, C.W. 2011. Christian Materiality: An Essay on Religion in Late Medieval Europe. New York: Zone Books.

Camille, M. 1998. Sensations of the Page: Imaging Technologies and Medieval Illuminated Manuscripts. In The Iconic Page in Manuscript, Print, and Digital Culture, eds. G. Bornstein and T.L. Tinkle, 33-53. Ann Arbor, MI: University of Michigan Press.

Casagrande, C. 2016. From Vigilance to Temperance: The Senses, the Passions, and Sin. In A Feast for the Senses: Art and Experience in Medieval Europe, ed. M. Bagnoli, trans. S. Switzer, 85-93. Baltimore, MD: Walters Art Museum.

Dailey, P. 2012. The Body and Its Senses. In The Cambridge Companion to Christian Mysticism, eds. A.M. Hollywood and P.Z. Beckman, 264-276. Cambridge, UK: Cambridge University Press. 
Dillon, E. 2012. The Sense of Sound: Musical Meaning in France, 1260-1330. Oxford, UK: Oxford University Press.

Gertrude d'Helfta. 1968, 1978, and 1986. CEuvres Spirituelles, eds. and trans. P. Doyère, J-M. Clément, Les Moniales de Wisques, and B. de Vregille, Sources Chrétiennes 139, 255, and 331. Paris, France: Éditions du Cerf.

Gertrud die Grosse von Helfta. 1989. Gesandter der göttlichen Liebe [Legatus divinae pietatis], trans. J. Lanczkowski. Heidelberg, Germany: Schneider.

Gertrude the Great of Helfta. 1991. The Herald of God's Loving-Kindness: Books 1 and 2, trans. A. Barratt. Kalamazoo, MI: Cistercian Publications.

Gertrude the Great of Helfta. 2018. The Herald of God's Loving-Kindness: Book 4, trans. A. Barratt. Collegeville, MN: Cistercian Publications.

Griffiths, F.J., Starkey, K., eds. 2018. Sensory Reflections: Traces of Experience in Medieval Artifacts. Berlin, Germany: De Gruyter.

Grimes, L. 2007. Writing as Birth: The Composition of Gertrud of Helfta's Herald of God's Loving Kindness. Cistercian Studies Quarterly 42(3): 329-348.

Hamburger, J. 1997. Nuns as Artists: The Visual Culture of a Medieval Convent. Berkeley, CA: University of California Press.

Hamburger, J. 1998. The Visual and the Visionary: Art and Female Spirituality in Late Medieval Germany. New York: Zone.

Hamburger, J. 2000a. Seeing and Believing: The Suspicion of Sight and the Authentication of Vision in Late Medieval Art and Devotion. In Imagination und Wirklichkeit: Zum Verhältnis von mentalen und realen Bildern in der Kunst der frühen Neuzeit, eds. K. Krüger and A. Nova, 47-69. Mainz, Germany: Von Zabern.

Hamburger, J. 2000b. Speculations on Speculation: Vision and Perception in the Theory and Practice of Mystical Devotions. In Deutsche Mystik im abendländischen Zusammenhang: Neu erschlossene Texte, neue methodische Ansätze, neue theoretische Konzepte; Kolloquium, Kloster Fischingen 1998, eds. W. Haug and W. SchneiderLastin, 353-408. Tübingen, Germany: Niemeyer.

Harrison, A. 2008. 'Oh! What Treasure is in this Book?': Writing, Reading, and Community at the Monastery of Helfta. Viator 39(1): 75-106.

Hubrath, M. 1996. Schreiben und Erinnern: Zur 'memoria' im 'Liber specialis gratiae' Mechthilds von Hackeborn. Paderborn, Germany: Schöningh.

Hubrath, M. 1997. Monastische Memoria als Denkform in der Viten- und Offenbarungsliteratur aus süddeutschen Frauenklöstern des Spätmittelalters. Zeitschrift Für Literaturwissenschaft Und Linguistik 105(1): 22-38.

Hubrath, M. 1999. The Liber specialis gratiae as a Collective Work of Several Nuns. Jabrbuch der Oswald-von-Wolkenstein-Gesellschaft 1: 233-44.

Jung, J.E. 2010. The Tactile and the Visionary: Notes on the Place of Sculpture in the Medieval Religious Imagination. In Looking Beyond: Visions, Dreams, and Insights in Medieval Art and History, ed. C. Hourihane, 203-240. Princeton, NJ: Index of Christian Art.

Kirakosian, R. 2021. From the Material to the Mystical in Late Medieval Piety: The Vernacular Transmission of Gertrude of Helfta's Visions. Cambridge, UK: Cambridge University Press.

Kolletzki, C. 1998. 'Über die Wahrheit dieses Buches': Die Entstehung des Liber Specialis Gratiae Mechthilds von Hackeborn zwischen Wirklichkeit und Fiktion. In 'Vor dir steht 
die leere Schale meiner Sehnsucht': Die Mystik der Frauen von Helfta, eds. M. Bangert and H. Keul, 156-79. Leipzig, Germany: Benno.

Largier, N. 2007. Die Applikation der Sinne: Mittelalterliche Ästhetik als Phänomenologie rhetorischer Effekte. In Das fremde Schone: Dimensionen des Ästhetischen in der Literatur des Mittelalters, eds. M. Braun and C. Young, 43-60. Berlin, Germany: De Gruyter.

Löser, F. 2012. Schriftmystik: Schreibprozesse in Texten der deutschen Mystik. In FindenGestalten - Vermitteln: Schreibprozesse und ibre Brechungen in der mittelalterlichen Überlieferung; Freiburger Colloquium 2010, eds. S. Köbele, K. Ridder, and E.C. Lutz, 155-201. Berlin, Germany: Erich Schmidt.

McGinn, B. 2012. Late Medieval Mystics. In The Spiritual Senses: Perceiving God in Western Christianity, eds. P.L. Gavrilyuk and S. Coakley, 190-209. Cambridge, UK: Cambridge University Press.

McNamer, S. 2010. Affective Meditation and the Invention of Medieval Compassion. Philadelphia, PA: University of Pennsylvania Press.

Nemes, B.J. 2014. Text Production and Authorship: Gertrude of Helfta's Legatus Divinae Pietatis. A Companion to Mysticism and Devotion in Northern Germany in the Late Middle Ages, eds. E. Andersen, H. Lähnemann, and A. Simon, 104-130. Leiden and Boston, MA: Brill.

Nemes, B.J. 2019. Scenes of Writing, Figurations of Authorship: A Literature Historian's Reflections on the Veracity of the Passages Recounting the Textual Genesis of the Special Edition of Gertrude of Helfta's Legatus divinae pietatis. Analecta Cisterciensia 69(1): 145-60.

Newhauser, R. 2014. Introduction: The Sensual Middle Ages. In A Cultural History of the Senses in the Middle Ages, ed. R. Newhauser, 1-22. London: Bloomsbury Academic.

Newhauser, R. 2015. The Senses, the Medieval Sensorium, and Sensing (in) the Middle Ages. In Handbook of Medieval Culture: Fundamental Aspects and Conditions of the European Middle Ages, ed. A. Classen, 1559-1575. Berlin, Germany: De Gruyter.

Palazzo, E. 2010. Art, Liturgy, and the Five Senses in the Early Middle Ages. Viator 41(1): $25-56$.

Poor, S. 2004. Mechthild of Magdeburg and Her Book: Gender and the Making of Textual Authority. Philadelphia, PA: University of Pennsylvania Press.

Rudy, G. 2002. In Mystical Language of Sensation in the Later Middle Ages. New York: Routledge.

Rudy, K.M. 2010. Dirty Books: Quantifying Patterns of Use in Medieval Manuscripts Using a Densitometer. Journal of Historians of Netherlandish Art 2(1-2), doi: https://doi.org/ 10.5092/jhna.2010.2.1.1.

Ruh, K. 1990. Franenmystik und franziskanische Mystik der Frühzeit, vol. 2 of Geschichte der abendländischen Mystik. Munich, Germany: Beck.

Ruh, K. 1992. Gertrud von Helfta: Ein neues Gertrud-Bild. Zeitschrift Für Deutsches Altertum Und Deutsche Literatur 121(1): 1-20.

Stock, B. 1983. The Implications of Literacy: Written Language and Models of Interpretation in the Eleventh and Twelfth Centuries. Princeton, NJ: Princeton University Press.

Voaden, R. 1997. All Girls Together: Community, Gender, and Vision at Helfta. In Medieval Women in Their Communities, ed. D. Watt, 72-91. Toronto, Canada: University of Toronto Press. 
Wenzel, H. 1995. Hören und Sehen, Schrift und Bild: Kultur und Gedächtnis im Mittelalter. Munich, Germany: Beck.

Williamson, B. 2013. Sensory Experience in Medieval Devotion: Sound and Vision, Invisibility and Silence. Speculum 88(1): 1-43.

Publisher's Note Springer Nature remains neutral with regard to jurisdictional claims in published maps and institutional affiliations. 